\title{
Outreach of Microfinance in India
}

\author{
Ravinder Kaur ${ }^{1}$

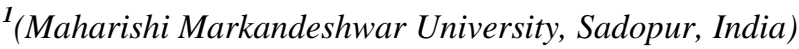

\begin{abstract}
Microfinance refers to small savings, credit and insurance services extended to socially and economically disadvantaged segments of society. It is emerging as a powerful tool for poverty alleviation in India. Various MFIs operate in India like Bandhan Financial Services Pvt. Ltd., BSS Microfinance Pvt. Ltd., Cashpor Micro Credit, Disha Microfin Pvt. Ltd., Equitas Microfinance Pvt. Ltd. and many more. The growing number of MFIs (Microfinance Institutions) in India calls for a need to study the extent to which these MFIs have enrooted in Indian economy. Client outreach and loan portfolio are two key indicators of an MFI's contribution to financial inclusion as well as the depth and breadth of financial deepening. This paper makes an attempt to study the outreach of Microfinance in India through the cliental base trends and some other important trends for past decade.
\end{abstract}

Keywords: microfinance, outreach, sustainability.

\section{INTRODUCTION}

With the rapidly increasing population of India, there was a need to make provision of equally efficient financial services. In order to meet the upcoming demands for credit a concept of microfinance emerged in India. Microfinance is a source of financial services for people lacking access or without full access to the financial sector. Microfinance enables them to take out loans to build or expand businesses and to make savings deposits.RBI defines microfinance as the provision of thrift, credit and other financial services and products of very small amounts to the poor in rural, semi-urban and urban areas for enabling them to raise their income levels and improve their living standards.

The microfinance industry has made good progress in improving understanding about issues related to institutional performance. Increasingly, outreach and sustainability have been adopted as the two main criteria used to assess the performance of microfinance organizations (MFOs). The concept of institutional sustainability has been debated and refined, methods have been developed to use MFO accounting data to measure sustainability, and several studies have reported the level of and trends in the sustainability of many MFOs. The conceptualization and measurement of outreach is not as well developed.

\section{OBJeCtive OF THE PAPER}

To study the outreach and trends of Microfinance Industry in India.

\section{RESEARCH METHODOLOGY}

Available secondary data was extensively used for the study. Different news articles, Books and Web were used which were enumerated and recorded.

\section{OUTREACH}

Active attempt to interact with clients in selected populations in geographic catchment areas and targeted initiatives. The cost of operations of MFIs depends upon the outreach (Figure 1).

\begin{tabular}{|l|l|l|l|}
\hline \multicolumn{5}{|c|}{ Fig. 1: Cost of Operations of MFIs } \\
\hline & NASCENT MFIS & GROWING MFIS & MATURE MFIS \\
\hline Annual outstanding & Less than 5 crs & $5-50$ crs & More than 5 crs \\
\hline Clients & Less than 10,000 & $10,000-1,00,000$ & More than 1,00,000 \\
\hline Operating cost $(\%)$ & $12-15$ & $10-12$ & $8-10$ \\
\hline Bad debts cost $\%)$ & $2-3$ & $1-2$ & $1-2$ \\
\hline
\end{tabular}


IOSR Journal of Business and Management (IOSR-JBM)

e-ISSN: 2278-487X, p-ISSN: 2319-7668

\begin{tabular}{|l|l|l|l|}
\hline Cost of funds (\%) & $16-20$ & $10-15$ & $7-9$ \\
\hline \multicolumn{3}{|c|}{ SOURCE: Mahajan and Ramola (1996) } \\
\hline
\end{tabular}

To increase the outreach, the MFIs should combine and rearrange the outreach aspects based on their strength. MFIs usually have high length and can focus on scope, cost, worth and breadth.Higher outreach by MFIs in Indian microfinance market have been characterised by doorstep lending, low transactions cost, less transition period and development of simple application procedure for clients. MFIs could also able to maintain the growth of outreach by attaining institutional sustainability by bringing down the administrative/operational costs to a lower level and working out on decentralised and simplified operations including procedures for approval, disbursement and recovery(Christen,2006). The most important revolution in microfinance operations was lending based on peer pressure and moral collateral; and using this techniques, MFIs have started bringing more and more clients in their books even if the clients did not have sufficient collateral.

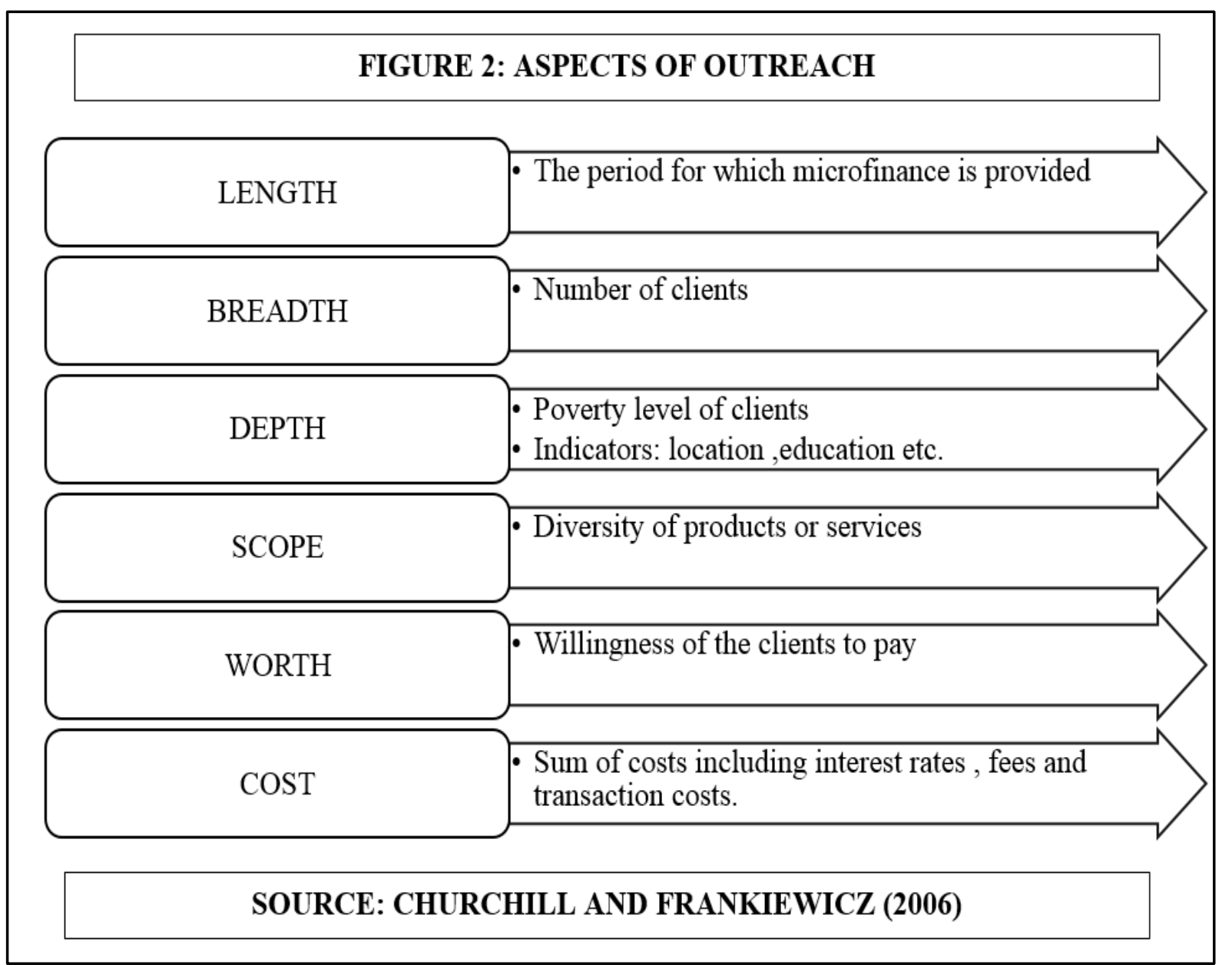

\section{OUTREACH AND SustainabiLITY}

In view of burgeoning outreach of MFI model, now-a-days, concern is centered on the sustainability of the program. Sustainability and outreach are widely discussed issues in the field of microfinance and two strands of thought emerge in this connection- "The Poverty Camp" and "The Sustainability Camp" (Morduch 2000). Although it is viewed by some thinkers that sustainability and outreach are competitive, some others indicate it as complementary in nature. It therefore can be implied that sustainability is the means to achieve outreach. Sustainability of a program indicates permanency in realizing the intended goal of the program. A MFI might help the poor now, but it cannot help the poor in the future if it could not survive. A financially self-sufficient MFI would earn so much profit that when donors leave, it will not shrink in real terms nor will it reduce the size or coverage of its service to the poor in future (Bhanot and Bapat,2015). 
In the wake of persistent poverty and budding of MFIs, outreach is perceived goal from social and business point of view. The gloomy part of the story looms when the issue of sustainability of the microfinance program have come out since it is observed that only few percent of the MFIs are sustainable to run operation without subsidies (Hulme and Mosley ,1996).

Outreach and impact are complementary in nature in achieving microfinance sustainability. The concept cannot be applied in general as in some cases outreach and sustainability is competitive and sustainability pre-conditioned on the reduction or removal of subsidy on microfinance. It also requires a well recovery rate, which can further help in outreach of the program. A deep attention on the concept can be attracted by taking the case of depth of outreach. For example, when an MFI serve a section of population who lives below poverty line, the probability of poor repayment in the case of adverse economic shocks to their lives increases delinquency rate. While even a small delinquency rate can cause more annual loss of loan, thus loan loss provision increases their cost segment (Rosenberg 1999).

$5.1 \quad$ TRENDS

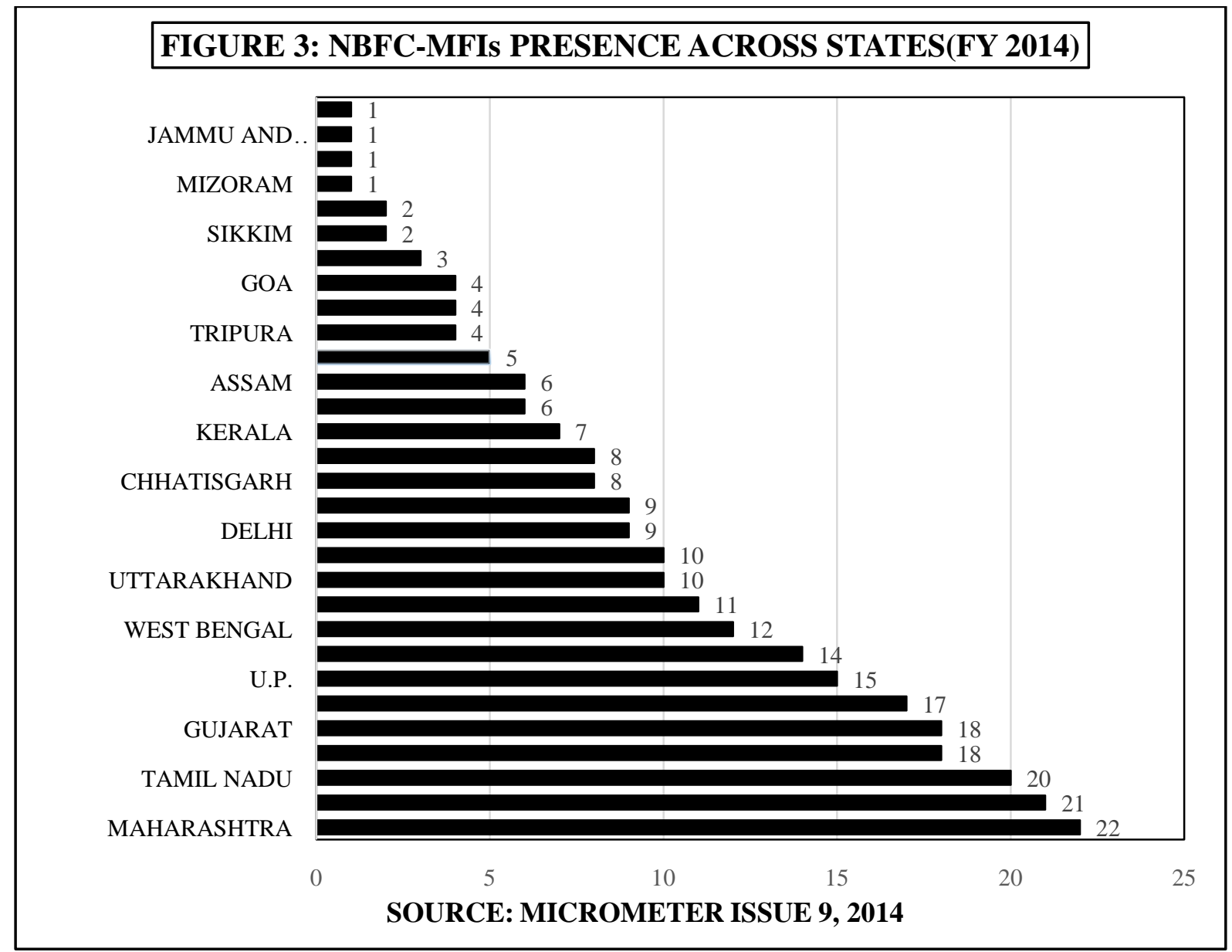

As per the report by Bharat Microfinance Report 2015, the MFIs in India had been consolidating their operations to cope with the effects of transition taking place in the sector. While 2012 and 2013 witnessed a decline in the branch network, the trend was arrested in 2014.In 2014 -15 too, MFIs have expanded their branches, posting a marginal growth of $4.57 \%$. As of March 2015, the reporting MFIs had 12221 branches spread across India. The distribution of branches among different categories of MFIs as of March 2015 showed that NBFC-MFIs had the lion's share of 10569 branches. Moreover, the report stated that Twenty-nine MFIs with a large outreach and portfolio have operations in more than five states, out of which five leading MFIs are operating in more than fifteen states.Figure 3 shows the presence of NBFC-MFIs across states in Financial 
Year 2014 highest being in Maharashtra followed by Madhya Pradesh, Tamil Nadu, Gujarat, Bihar , Uttar Pradesh and so on with the lowest number in Mizoram , Manipur, Jammu and Kashmir.

\subsection{Cliental Outreach OF MFi}

Figure 4 shows that the total number of clients served by MFIs stood at 371 lakhs as on 31 March, 2015. Client outreach of MFIs had grown substantially from 2005 to 2011, reaching a level of 371 lakhs. This trend slowed down during 2012 and 2013 and the number of clients slumped to 275 lakhs. The trend reversed in 2014 with a growth and reached a level of 330 lakhs. This trend continues in 2015 with an astounding rise in clients/borrowers to an all-time high of 371 lakhs. Majority of these clients are being served by NBFC-MFIs $(85.18 \%)$, primarily the larger ones.
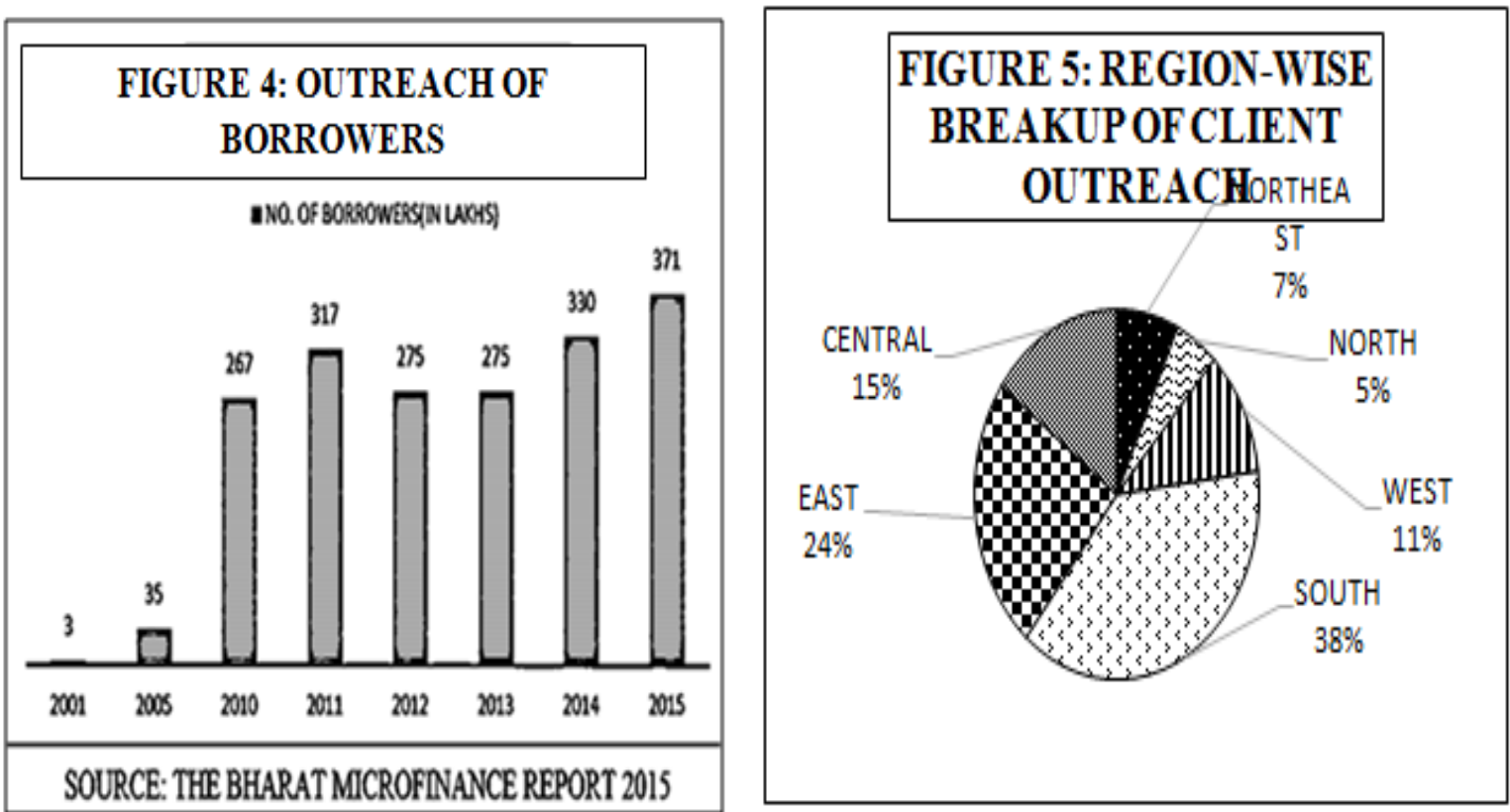

\subsection{REgional OUtREACH ON MFI}

With the increase in cliental base over number of uears, there is also tremendous increase in the number of clients in different regions of India. Figure 5 shows the region-wise breakup of client outreach in India. Out of the total client base of 371 lakhs in 2015, South alone contributes to 39\% followed by 25\% in East. Central region and West have $15 \%$ and $11 \%$ of total outreach respectively. Northeast and North have the least client outreach numbers with $6 \%$ and $4 \%$ respectively. Share in outreach has expanded only in case of Central and North east regions from 13 to $15 \%$ and 5 to $6 \%$ respectively.

Figure 6 shows the top 10 states in terms of number of unique clients. Whileclients in Andhra Pradesh are largely inactive, WestBengal and Tamil Nadu continue the last year's trendof accounting for largest number of clients followed byMaharashtra and Karnataka.

\section{Regional Spread of Loan Portfolio:}

Among the regions, South still dominates the overall loan portfolio outstanding of MFIs with 39\% followed by East with 24\%. Central and West have 15\% and $11 \%$ respectively. While Northeast and North have least portfolio share of 7\% and 5\% respectively (Bharat Microfinance Report 2015).

Average loan outstanding per borrower has been an important criterion to understand the general profile of clients borrowing from MFIs (a surrogate indicator for depth of outreach). It has implications on operating cost as well as the adequacy of loan amount for the purpose it was borrowed. 


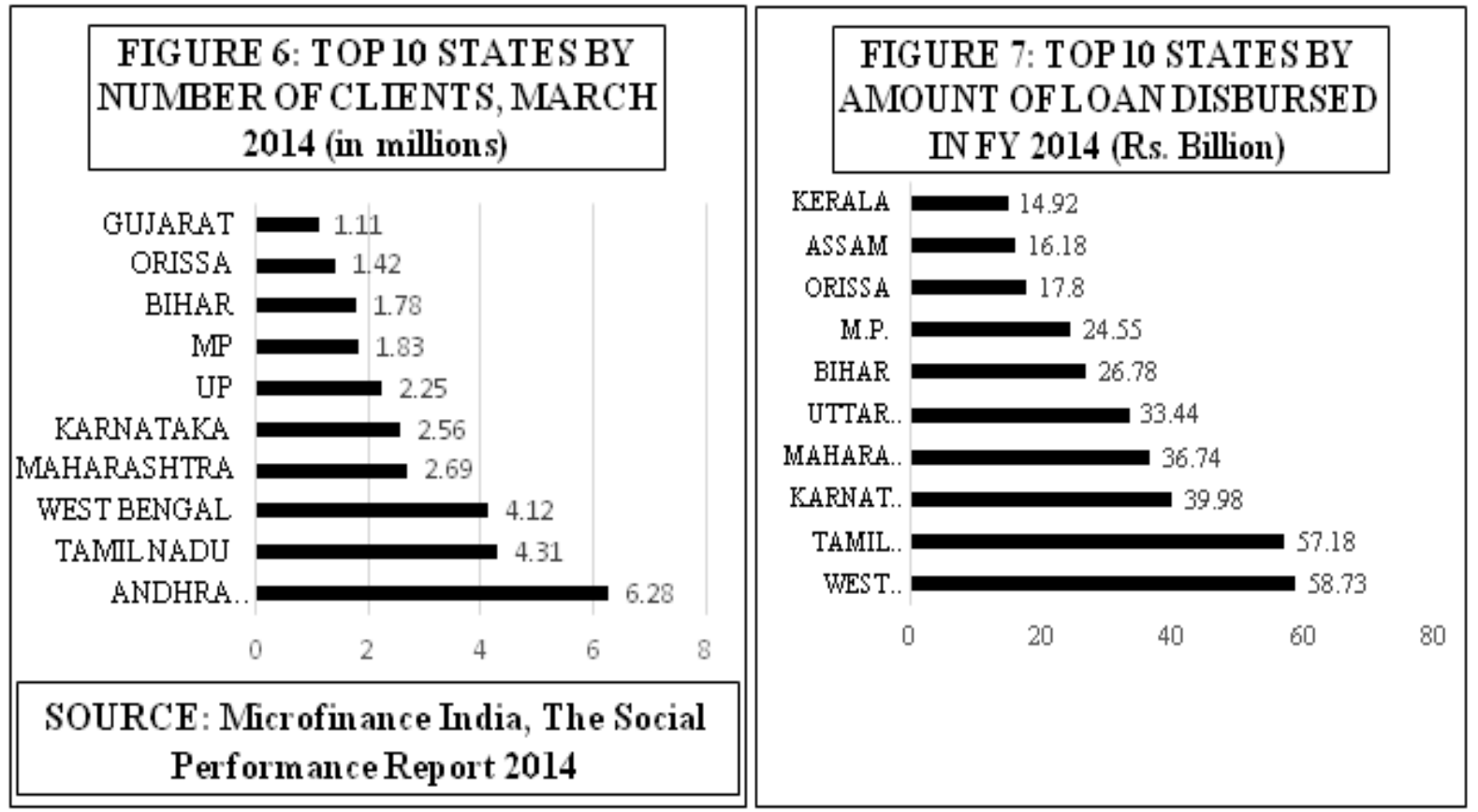

While inclusion of the North-eastern state of Assam in the top 10 states (see Figure 7) is a positive sign, it $\mathrm{s}$ a matter of concern in view of regional penetration that the top 10 states account for 86 per cent of the total loan amount disbursed by MFIs during the year.

A small sample survey of MFIs conducted by ACCESS ASSIST (2014) indicates that the percentage of active women clients has declined over the last three years from 99.5 per cent in 2013 to 97 per cent in 2014 . Rural clients constitute 54 per cent of the total client outreach in the sample MFIs. However, 33 out of 36 reporting MFIs indicate women as their target market segment and 21 reported targeting rural clients. Data analysis from ACCESS ASSIST (2014) survey also indicates that 83 per cent loans are for livelihoods, with social loans and housing loans comprising 6 per cent and 7 per cent respectively (increased from 4 per cent each in 2013survey results) (see Figure 8).

\begin{tabular}{|lcccc|}
\hline \multicolumn{5}{c|}{ FIGURE 8: LOAN PURPOSE } \\
\hline Loan Products & $\begin{array}{c}\text { No. of MFIs } \\
\text { offering }\end{array}$ & $\begin{array}{c}\text { Number of clients } \\
(\mathrm{Mn})\end{array}$ & $\begin{array}{c}\text { Loan outstanding } \\
\text { (Rs Mn) }\end{array}$ & $\begin{array}{c}\text { Average loan } \\
\text { size (Rs) }\end{array}$ \\
\hline Agricultural and Allied loan & 8 & 1.6 & 18,441 & 11,189 \\
Enterprise / IGA & 39 & 12.1 & 72,312 & 5,958 \\
Water/Sanitation Loan & 10 & 0.2 & 1,120 & 4,546 \\
Education Loan & 11 & 0.1 & 1,064 & 9,465 \\
Health Loan & 3 & 0.01 & 74 & 7,067 \\
Housing Loan & 10 & 0.2 & 7,828 & 38,439 \\
Social Loan* & 9 & 0.5 & 7,019 & 13,017 \\
Emergency / Misc. Loan & 13 & 1.1 & 1,366 & 1,272 \\
& $\mathrm{n}=39$ & 16.0 & 109,226 & $\mathbf{6 , 8 3 8}$ \\
\hline Source Small Sample study by ACCESS ASSIST 2014. & & & \\
* Includes loans for jewellery purchase, marriage, festival, cook stoves. & & & \\
** Includes welfare, gold loans, and combo loans. & & & \\
\hline
\end{tabular}

RBI stipulates minimum loan tenure of 24 months for loans above Rs 15,000. Figure 9 shows 67per cent of active loans with tenure between 12 and 24 months and 14 per cent over 24 months, which aligns both with the distribution of loans according to sizes and with the regulatory considerations. 


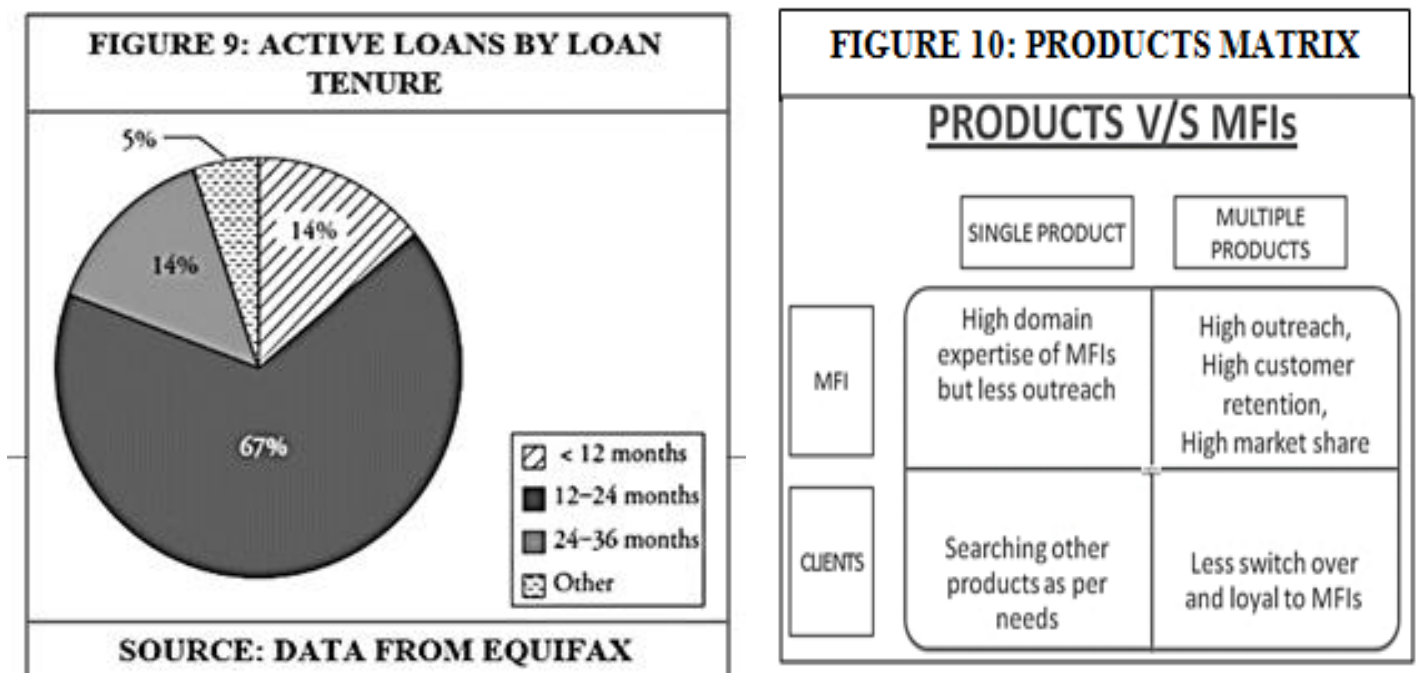

Outreach To Special Segment Of Borrowers (Women, Sc/St, AND Minorities)

World over the focus of microfinance has always been on serving women. In India as an alternate vehicle ofcredit, microfinance serves a large segment of people from Scheduled Castes, Scheduled Tribes and Minorities.Women clients constitute $97 \%$ of the total clients of MFIs. Similarly, SC/ST borrowers also constitute asubstantial chunk (28\%) of the clients.As per the NSS data of various years, including the latest one of 2013, majority of the population is stilldependent largely on informal and expensive sources, including money lenders to meet their credit needs.Credit needs for such a population range from emergency loans, consumption loans, business loans, workingcapital loans, housing etc. Credit is the flagship service offered by MFIs to clients outside the net of formalfinancial services. For MFIs, loan portfolio is the primary revenue generating asset. It also gives details aboutthe health of MFIs through financial performance, as the financial performance is a function of revenue andcost. As of March 2015, the total loan portfolio of MFIs has reached an all-time high of over ₹ 48882 crores which is a $46.89 \%$ growth over last year crore that also includes a managed portfolio of nearly ₹9854 crores (Microfinance Market Outlook,2015).

\section{Outreach in Asia-pacific regions:}

Growth fundamentals in the main microfinance markets in Asia Pacific are relatively solid, with the exception of Mongolia, which will be strongly affected by the end of the commodity super-cycle and the downturn in China. Microfinance markets in India and Cambodia are expected to expand at their current pace; India in particular can benefit from higher growth potential as well as a more favorable regulatory environment. The deceleration in Mongolia will weigh slightly on the overall growth outlook; nevertheless, Asia Pacific is expected to grow by around $30 \%$ in 2016 .

Over the last six years, India's microfinance sector has experienced a rollercoaster ride with remarkable results. In 2010, a promising growth story was abruptly interrupted by one of the biggest crises microfinance has experienced to date. The government of Andhra Pradesh, then governing a population the size of Germany, shut down the local microfinance sector, with drastic consequences. The state government's move led to a complete halt of microfinance across the state, triggering an identity crisis and serious funding shortages throughout India's microfinance sector.

\section{Recent Strategies Of MFIs In Increasing Outreach}

- Integration of various microfinance products

MFIshave come up with the provision of various microfinance products together as a package or as an individual product to the clients. For example; MFIs provide credit, savings, money transfer, insurance etc. together. ADHIKAR Micro fin in collaboration with ICICI bank had financed Rs 20,000 to 530 poor households for construction and repair of the house, provided life insurance and provided payment transfer services to clients. Its remittance work started from Gandhidham.

\section{- Customizing financial products and delivery systems}


Another way of increasing outreach of an MFI is to customize the products according to the needs of the customers. For example,Union Bank of India has designed a "biometric smart card technology" for the hawkers of Mumbai.Even an illiterate hawker can transfer the amounts instantly through the bank network spread across India. It was done to protect the hawkers from private moneylenders (for loans) and non-formal agencies (for savings).

- Adopting multiple lending models

ADHIKAR micro fin (Orissa based NGO-MFIs) provides microfinance products and services through various models like Joint Liability Group $\{\mathrm{JLG}\}$ model with Repayment rate - 99.7\% and Cooperative model designed for rural women with 34 cooperatives including 565 males and 10982 females.

- Line extension of a microfinance product

Line extension is a route to provide need based products. For example; Madura Micro Finance Ltd. is an NBFC (Non-Banking Finance Company) with a mission to deliver viable credit to micro entrepreneurs with the greatest potential to create scalable enterprise and economic value. Since its founding in 2006 Madura has disbursed over 9 billion Rupees (over \$150 million) in micro loans to over 500,000 people across 2000 villages in Tamil Nadu. Recognized by Forbes (in the company's previous namesake, Microcredit Foundation of India) as the most cost efficient microfinance institution worldwide, Madura has consistently been able to lend profitably at the lowest rates on the market. Committed to bringing greater intelligence to identifying and enabling micro entrepreneurs Madura's labs have built large scale mechanisms for aggregating hard to acquire or 'dark' data from rural areas, delivering analytic insights and knowledge products that enhance microenterprise outcome and predict enterprise revenue capability.

\section{- Partnership and inter collaboration of MFIs}

To speed up the penetration of microfinance products and services into rural and urban slums of India partnership and inter collaborations of MFIs was done. For example: SKS Microfinance is honored to work with a world class group of partners and supporters. When it started out as a small NGO, SKS received early support from close friends and family of the founder. As the organization grew, so did its list of partners, starting with leading foundations and donor organizations, like Women's World Banking), CGAP, Grameen Foundation USA and American India Foundation. Now as a Non-Banking Financial Company - Micro Finance Institution (NBFC-MFI) registered and regulated by the Reserve Bank of India, some of the largest banks and investors work with SKS. HSBC made its first

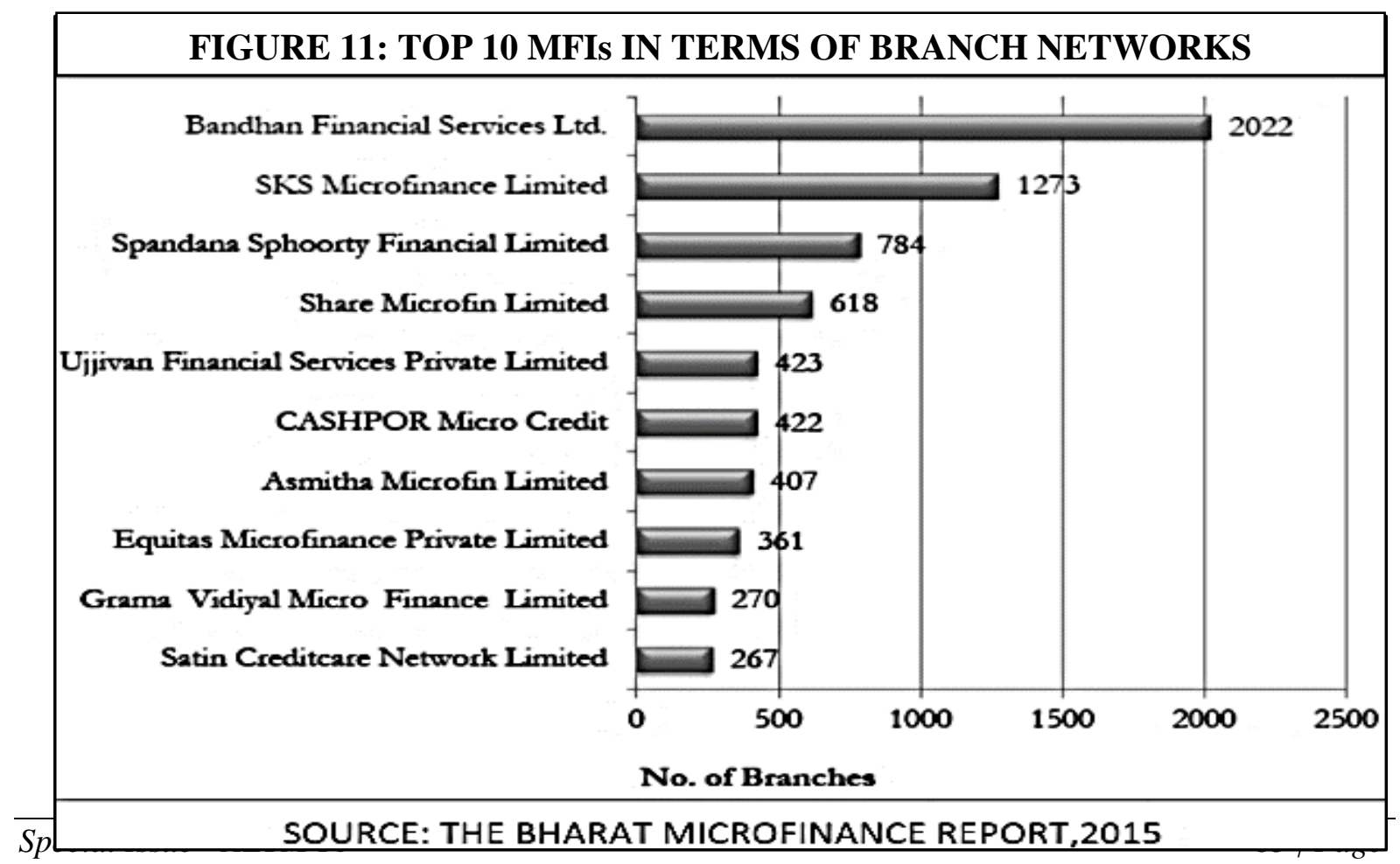


microfinance loan to SKS and Citibank made its first microfinance loan in India to SKS. SKS is also an active participant in global microfinance associations, such as MIX Market and Microfinance Network. SKS Microfinance had tied up with LIC and many others to provide health insurance and it covered 1, 50,000 clients and their spouses in case of death.

\subsection{OUTREACH OF 'BANDHAN'}

Figure 11 shows that BANDHAN Financial Services Ltd. has the highest number of braches out of top 10 MFIs. BANDHAN, an MFI registered under NBFC Act, opened its first microfinance branch at Bengal in Howrah district of West Bengal in July, 2002.BANDHAN was set up to achieve the dual objective of poverty alleviation and women empowerment. A Aspiring to holistic development of poor, BANDHAN supports several development activities through it's not for profit entity. At present, its intervention areas are health, education, unemployment, livelihoods etc.

\begin{tabular}{|l|l|}
\hline \multicolumn{2}{|c|}{$\begin{array}{r}\text { FIGURE 12: OUTREACH OF BANDHAN } \\
\text { (AS ON JUNE,2015) }\end{array}$} \\
\hline Spread & Across 22 states and union territories \\
\hline Disbursed & $₹ 1,601$ crores \\
\hline Branches & 2,022 \\
\hline Employees & 13,067 \\
\hline Borrowers & $67,17,331$ \\
\hline \multicolumn{2}{l}{ Source: $\underline{\text { http://www.bandhanmf.com/bn_default.aspx }}$} \\
\hline
\end{tabular}

It aims to deliver these services to the entire community in an innovative and sustainable manner.

Figure 13 shows the outreach of Bandhan as reported by CRISIL in a repoet submitted in June 2014. As a new entrant BANDHAN focused on the worth, scope and cost of outreach. The financial statements and Balance Sheet of Bandhan of recent years shows that it has achieved remarkable growth in past years.
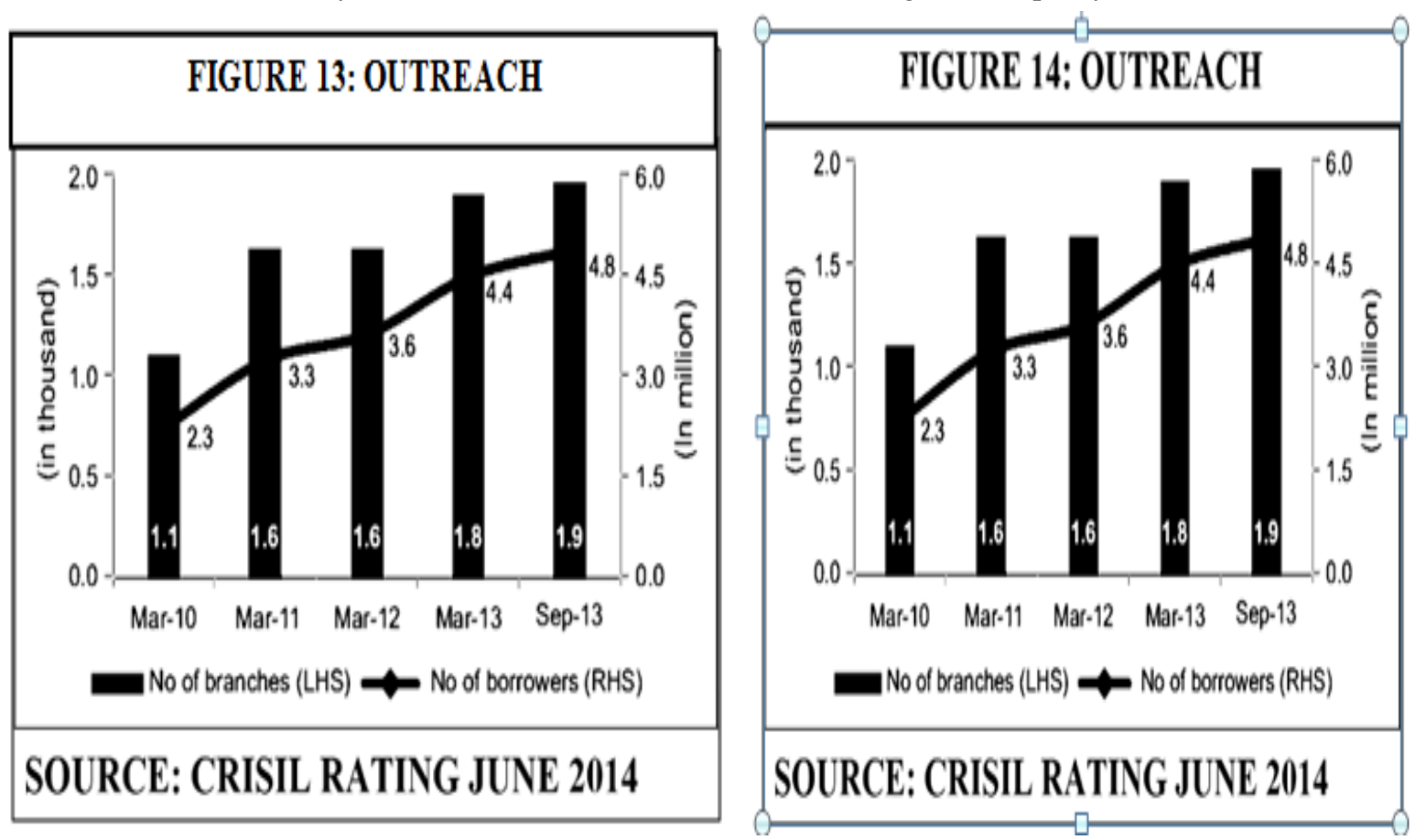
IOSR Journal of Business and Management (IOSR-JBM)

e-ISSN: 2278-487X, p-ISSN: 2319-7668

\begin{tabular}{|c|c|c|c|c|c|c|}
\hline \multirow{2}{*}{$\begin{array}{l}\text { Income and Expenditure Statement } \\
\text { Year ended March 31, }\end{array}$} & \multicolumn{6}{|c|}{ Rs. crore } \\
\hline & FY10 & FY11 & FY12 & FY13 & FY14 & FY15 \\
\hline 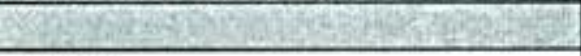 & \multicolumn{3}{|c|}{ (Audited) } & \multicolumn{3}{|c|}{ (Projected) } \\
\hline \multicolumn{7}{|l|}{ Income } \\
\hline Interest Income on own portfolio & 222.1 & 427.1 & 680.4 & 917.2 & $1,270.2$ & $1,619.7$ \\
\hline Other Operating Income & 51.9 & 93.9 & 107.8 & 129.9 & 107.8 & 96.5 \\
\hline Total Income & 274.0 & 521.0 & 788.2 & $1,047.1$ & $1,378.0$ & $1,716.2$ \\
\hline \multicolumn{7}{|l|}{ Financial Costs } \\
\hline Interest expense on own portfolio & 94.6 & 196.6 & 278.6 & 452.4 & 611.1 & 795.3 \\
\hline Total Financial Costs & 94.6 & 196.6 & 278.6 & 452.4 & 611.1 & 795.3 \\
\hline Net Interest Income & 179.4 & 324.4 & 509.6 & 594.7 & 766.9 & 920.9 \\
\hline \multicolumn{7}{|l|}{ Operating Expenses } \\
\hline Operating Expenses & 57.2 & 115.4 & 137.2 & 182.0 & 270.8 & 370.9 \\
\hline Depreciation & 7.8 & 17.4 & 36.6 & 10.4 & 3.6 & 4.6 \\
\hline Total Operating Expenses & 65.0 & 132.8 & 173.8 & 192.4 & 274.4 & 375.5 \\
\hline Net income Before Loan Loss & 114.4 & 191.6 & 335.8 & 402.3 & 492.5 & 545.4 \\
\hline Provisions \& write off & 0.5 & 13.6 & 37.5 & 38.2 & 52.6 & 43.9 \\
\hline PBT & 113.9 & 178.0 & 288.9 & 353.1 & 426.8 & 486.3 \\
\hline PAT & 73.9 & 117.6 & 188.1 & 219.5 & 263.2 & 305.1 \\
\hline
\end{tabular}

\begin{tabular}{|c|c|c|c|c|c|c|}
\hline \multirow{2}{*}{$\begin{array}{l}\text { Balance Sheet } \\
\text { As on March 31, } \\
\end{array}$} & \multicolumn{5}{|c|}{ 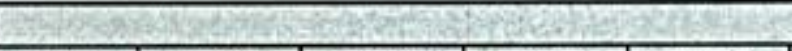 } & \multirow{2}{*}{$\frac{\text { Rs. crore }}{\text { FY15 }}$} \\
\hline & FY10 & FY11 & FY12 & FY13 & FY14 & \\
\hline 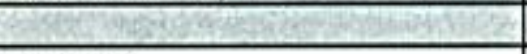 & \multicolumn{3}{|c|}{ (Audited) } & \multicolumn{3}{|c|}{ (Projected) } \\
\hline Liabilities & & & & $\cdot$ & & \\
\hline \multicolumn{7}{|l|}{ Source of Funds } \\
\hline \multicolumn{7}{|l|}{ Tangible Networth } \\
\hline Share Capital & 76.33 & 86.33 & 96.90 & 246.90 & 246.90 & 246.90 \\
\hline Reserves and surplus & 125.62 & 290.06 & 593.00 & 822.70 & 1085.80 & 1390.90 \\
\hline Total Tangible Networth & 201.95 & 376.39 & 689.90 & $1,059.40$ & $1,322.50$ & $1,627.60$ \\
\hline \multicolumn{7}{|l|}{ Debt Fund } \\
\hline Term loans from Bank \& FIs & $1,337.82$ & $1,847.64$ & 3364.90 & $4,298.50$ & $5,432.50$ & $6,849.50$ \\
\hline Total Debt & $1,337.82$ & $1,847.64$ & 3364.90 & $4,298.50$ & $5,432.50$ & $6,849.50$ \\
\hline Total Capital Employed & $1,539.77$ & $2,224.03$ & 4054.80 & 5368.10 & 6765.20 & 8487.40 \\
\hline \multicolumn{7}{|l|}{ Assets } \\
\hline \multicolumn{7}{|l|}{ Application of funds } \\
\hline Net fixed assets & 57.79 & 49.99 & 16.40 & 9.00 & 9.80 & 8.80 \\
\hline Investments & 0.20 & 0.20 & 0.20 & 0.20 & 0.20 & 0.20 \\
\hline \multicolumn{7}{|l|}{ Current assets } \\
\hline Cash \& bank balances & 601.15 & 538.51 & 1132.60 & 662.00 & 706.20 & 745.30 \\
\hline Own portfolio & $1,195.05$ & $2,106.50$ & 3079.50 & $4,833.20$ & $6,253.70$ & $7,999.90$ \\
\hline Other current assets & 53.99 & 46.23 & 36.90 & 0.00 & 0.00 & 0.00 \\
\hline Total Current Assets & $1,850.19$ & $2,691.24$ & 4248.90 & 5495.20 & 6959.80 & 8745.20 \\
\hline Current liabilities and provisions & 368.41 & 517.40 & 210.70 & 136.30 & 204.60 & 266.80 \\
\hline Net Current Assets & $1,481.78$ & $2,173.84$ & $4,038.20$ & $5,358.90$ & $6,755: 20$ & $8,478.40$ \\
\hline Miscellaneous expenses not written off & $\cdot$ & - & & & & \\
\hline Total Application of Funds & $1,539.77$ & $2,224,03$ & 4054.80 & 5368.10 & 6765.20 & 8487.40 \\
\hline
\end{tabular}




\section{CONCLUSION}

Microfinance institutions are considered as an effective tool to deal with a major issue of Indian economy named as poverty. Like many popular mass movements, the microfinance movement is characterized both by widespread agreement on broad objectives and by multiple rifts on key issues. The movement itself is driven by the shared commitment to provide credit for small enterprise formation and growth. It is also bound together by a common rhetoric of concern for the poor. the microfinance industry is growing at a fast pace and can be understood as a supplement to poverty alleviation programmes in India.

\section{REFERENCES}

[1] R.P. Christen, "Microfinance and sustainability: International experiences and lessons for India in Towards a Sustainable Microfinance Outreach in India", NABARD, GTZ and SDC, 2006, 43-67.

[2] V. Mahajan, and B. G. Ramola, "Financial services for the rural poor and women in India: Access and sustainability". Journal of Int. Dev., 8(2), 1996, 211-224.

[3] N. Marakkath and L. Attuel-mendes, "Can microfinance crowdfunding reduce financial exclusion? Regulatory issues", International Journal of Bank Marketing, 33(5), 2015, 624 - 636.

[4] R. Rosenberg, "Measuring Microcredit Delinquency: Ratios Can Be Harmful to Your Health, Consultative Group to Assist Poorest, 3 1999.

[5] J. Morduch, "The Microfinance Schism", World Development, 28(4), 2000, 617-629.

[6] D. Hulme, and P. Mosley, Finance Against Poverty, Routledge, New York, 1, 1996, 16-26.

[7] D. Bhanot and V. Bapat, "Sustainability index of micro finance institutions (MFIs) and contributory factors", International Journal of Social Economics, 42(4), 2015, 387 - 403.

[8] Hartarska, Valentina and N. Denis, "Do Regulated Microfinance Institutions Achieve Better Sustainability and Outreach?" Cross Country Evidence. Applied Economics, 39(10-12), 2009, 1207-1222.

[9] P. K. Debadutta, Understanding microfinance (New Delhi: Wiley-India Pvt. Ltd., 2010).

[10] G. Srinivasanan, Microfinance India: The Social Performance Report 2014, (New Delhi: Oxford Publishing house, 2015).

[11] 'Calmeadow's Microfinance Reference Guide' retrieved from http://www.gdrc.org/icm/calmeadow-kbdef.html.

[12] 'The Bharat Microfinance Report 2015' retrieved from http://indiamicrofinance.com/wp-content/uploads/2015/10/BharatMicrofinance-Report-20151.pdf

[13] 'Microfinance Market Outlook' 2015 retrieved from http://www.responsability.com/funding/data/docs/es/10427/Microfinance-MarketOutlook-2015-DE.pdf.

[14] Access Assist Report on Human Resource Management in Microfinance Institutions: The State of Practice, study by Hexa Resource Axis India Private Limited, New Delhi, covering 25 MFIs, (2014).

[15] 'Code of Conduct Assessment of Equitas' (2014) Available at http://sidbi.in/sites/default/files/products/COCA\%20ReportEquitas\%20 Microfinance \%20India\%20Pvt\%20Ltd.pdf.

[16] Crisil, 'India's Leading 25 MFIs' retrieved from http://www.crisil.com/pdf/ratings/indias-25-leading-mfis.pdf, 2014.

[17] http://www.bandhanmf.com/

[18] http://www.adhikarindia.org

[19] http://www.sksindia.com/index.php

[20] http://maduramicrofinance.com/products.html

[21] http://www.sksindia.com/partners.php

[22] http://www.equitasmf.in/

[23] https://www.nabard.org/Publication/SMFI_2013_14.pdf

[24] http://www.bandhanmf.com/report/MicroMeter_Mar_2013_Issue_5.pdf 